\title{
Corrosion of Stainless Steel and its Prevention through Surface Modification for Biomedical Application: A Review
}

\author{
Srikant Tiwari and S. B. Mishra \\ Department of Mechanical Engineering, Motilal Nehru National Institute of Technology, Allahabad, Uttar Pradesh, India \\ E-Mail:sbmishra@mnnit.ac.in
}

\begin{abstract}
Living habits of the young as well as old age people is changing with the advancement of technology. The number of accidents of young age group is increasing due to faster life causing bone fracture whereas bone fracture or misalignment of joints is common amongst the old aged people. Various natural and artificial materials such as (Stainless steel (SS), titanium alloys, cobalt alloys, nickel alloys etc.) are used as biomaterials to replace the damaged body parts. Among the various biomaterials, stainless steel is widely used due to its ease of processing, shaping, low cost and availability. However, its behavior is quite different in human body condition and faces several problems such as wear, lack of biocompatibility, corrosion, etc. Corrosion is reported to be a serious concern related to biomaterials especially stainless steel as it releases toxic elements which are harmful to human body and causes several others serious problems. This paper presents a critical review on the corrosion behavior of stainless steel biomaterial, others problem/issues associated with the stainless steel and surface modifications techniques/methods to improve the corrosion resistance, wear resistance, biocompatibility and overall life of such implants.
\end{abstract}

Keywords: Biomaterial, Implants, Biocompatibility, Tribological, Biological

\section{INTRODUCTION}

Biomaterials are artificial or natural materials which are used to manufacture structure or implants in order to replace non-functional part to restore form and function of joints or bone lost due to accident or disease[1]. These materials are used in different forms in human body for example, artificial heart valves, blood vessels stents, in shoulders, knees, hips, and elbows joints [2].The primary requirement for the selection of the biomaterial is its compatibility with the human body. It should not have any adverse effects such asallergies, swellingandpoisonousnessaftersurgery [3]. Secondly, it should not undergoes fracture when subjected to fluctuating load and more importantly, a biomaterial as an implant must have excellent resistance to corrosion and wear resistance in highly corrosive body condition[4].Currently, 316L stainless steel,titanium-based alloys and cobalt chromium alloys are used for orthopedic applications[5]. Among these, stainless steel is widely used due to its better bioactivity with tissues and bones, superior corrosion resistance in the body fluid, noblecombination of high strength and low modulus, high fatigue and wear resistance, low cost, ease of fabrication and welding[6].Various types of Stainless steels are widely used for different applications, for example, Martensitic steel is used for dental and surgical application, austenitic steel is used in short term implants, knee joints, total hip replacement etc. [7].However, the behavior of stainless steel is very different in human body fluid condition and it is prone to pitting and crevice corrosion. It releases metallic ions release such as Nickel (Ni), Cobalt (Co), and Molybdenum (Mo) in the body which in excess can causes detrimental effect on health[8]. It also reduces the extent of biocompatibility of SS and reduce the implant life in the body[9].In this paper, issues related to corrosion and its remedies through surface modification of SS for biomedical applications and biocompatibility has been reviewed.

\section{CORROSION OF STAINLESS STEEL}

Corrosion is one of the biggest problem that occurs when a metal and alloys are used as implants. In order to reduce or control the occurrence of corrosion, better understanding of corrosion mechanism is necessary [10]. Stainless steel is stable in atmospheric condition and do not corrode easily. However, it suffers from localized corrosion in the severe environment of human body which contains different types of extracellular and intercellular fluid containing water, dissolved oxygen, enormous amounts of sodium and chloride ions. Other electrolytes such asbicarbonate and minor concentration of potassium, calcium, magnesium, phosphate, sulphate, amino acids, proteins, plasma, lymph etc. plays a role of catalyst in corrosion of implants [11]. These ions plays an important role in maintaining $\mathrm{pH}$ of body fluid.Implants corrosion in the body fluids takes place via electrochemical reactions [12]. It is a kind of oxidation and reduction reaction that occurs between metals in implants and dissolved oxygen in body fluid i.e. metals get oxidized to ionic state and the oxygen dissolved reduced to hydroxyl ion [13]. It is reported in the literatures that during corrosion total number of electron production and consumptionsareequal, but,overall redox reaction is controlled by slowest step among oxidation and reduction [14].

\section{ELECTROCHEMICAL CORROSION OF STAINLESS STEEL IN HUMAN BODY}

Corrosion in the stainless steel occur in different form namely pitting, crevice,galvanic, intergranular, stresscorrosion cracking, corrosion fatigue and fretting corrosion[15]. Among these, it has been found that $90 \%$ of 
fails due to pitting, and crevice corrosion and are discussed in brief below.

\section{A. Pitting Corrosion}

Pitting is a severe form of localized corrosion attack that leads to release of substantial amounts of metal ions [16]. It occurs due to breaking of passive layer causing anodic site fixed at small area i.e.irregularities in the surface caused due variation in metals, non-uniform coatings, scale deposition etc. [17], while, cathodic reason can lie at any point outside the pit because of it high corrosion current density generated at the pits base. Pitting generally occurs in form of small cavities/holes at the surface of a material. These pits/holes are formed due to interaction of attacking ions with the defective or weak locations on surface. It is a self-activating reaction mechanisms which initiates at the surface in variousforms and sizesand mostly depends on metallurgical property of the metal or alloy, the electrolyte and other electrochemical factors. However, it can be protected through adherent, firm and self-healing thin passive film 18]. In implants, screw heads and under side region are more prone to pitting and it is mostly accelerated by fluid containing chloride ions [19]. This can be controlled by increasing molybdenum content in the steel and keeping the inclusions as less as possible [20].

\section{B. Crevice Corrosion}

Crevice corrosion is a form of corrosion which is related to structural defects. Poor shielding of stainless steel surface from the environmental condition is a prime reason for the crevice corrosion [21]. In implants, it usually occurs at the positions where screw head holds the plate or at the junction of two components, hip nail etc. [22]. A narrow deep crack or crevice at interface of device or its part such as intersection of screw head and plate or defect at fatigue crack are the main target for the initiation of crevice corrosion.

Among different type of SS, 316L is highly prone to crevice corrosion attack [23]. It is most common in contact area between bone plate and screws made up of stainless steels[24]. Crack induces and propagates at countersink portion of the bone plate where chance of corrosion is very high and is hard to detect. Therefore, modification of material and design of devices may be effective to minimize crevice corrosion in SS [25].

\section{PROBLEM ASSOCIATED WITH STAINLESS STEEL}

There are three major factors based on which biomaterial is said to be stable in human body are: (i) mechanical, corrosion and tribological), (ii) compatibility with human body and (iii) the health condition of the patient [26]. The implants may fail due to lack of anyone or combinations of any of three factors. Out of all these issues, corrosion is one of the major challenges that is faced by the implants in the
body.Human body contains biological species which disturb the equilibrium of the corrosion reactions of the implant and causes leaching due to anodic or cathodic reactions [27].

It is observed that proteins present in body fluid bind to metal ions and take them away from the implant material surface and disturbing the equilibrium across the surface formed due to interaction of electrons on the surface and excess cations in the solution. Reduction in the oxygen diffusion is also a problem related to implants due to absorption of proteins on the surfaces and causes corrosion in a certain region [28]. At cathode, hydrogen evolves and act as corrosion inhibitor, however, the bacteria present in the body fluidabsorb the hydrogen available in the locality of implants and appears to change this behavior and accelerate corrosion. The value of $\mathrm{pH}$ in human body is usually maintained at 7.0 but it varies in different body condition, for example, due to accidental and biological disturbancespHvaries from 3 to 9 and after insertion of implants in body the $\mathrm{pH}$ varies in between 5.3 to 5.6 which is slightly acidic in nature and acts as a catalyst for corrosion of implants. Despite, the formation of protective oxide layer on the surface of most of the materials from environmental attack, there is a clinical proof of leaching of implants due to corrosion.

Austenitic stainless steels, most preferably surgical grade $316 \mathrm{~L}$ stainless steel is used routinely as a temporary implants in several countries[29]. According to ASTM standard $316 \mathrm{~L}$ is recommended for the implants fabricationdue to presence of less carbon in it, which decreases the chance of forming chromium carbide that generally results in intergranular corrosion. Lowering of the carbon content also makes this type of stainless steel more corrosion-resistant to chlorine-bearing solutions such as physiological saline in the human body[30]. However stainless steel is susceptible to localized corrosion by chloride ions and reduced sulfur compounds. The presence of microorganisms on a metal surface often leads to highly localized damages in the concentration of the electrolytic constituents, $\mathrm{pH}$ and oxygen levels [31].

TABle I EfFect Of Metal Ions On The Human Body[32]

\begin{tabular}{|c|c|c|}
\hline S.No. & Element & Effect on body \\
\hline 1 & $\mathrm{Ni}$ & Dermatitis, skin allergy \\
\hline 2 & $\mathrm{Co}$ & Anemia B \\
\hline 3 & $\mathrm{Cr}$ & Ulcers and Nervous problem \\
\hline 4 & $\mathrm{Al}$ & Alzheimer disease, Epileptic effects \\
\hline
\end{tabular}

Type $316 \mathrm{~L}$ stainless steel is stable in atmospheric condition but its behavior changes in the body environment and corrode readily by releasing $\mathrm{Co}$, Chromium $(\mathrm{Cr})$ and $\mathrm{Ni}$ ions which are found to be powerful allergens and carcinogens if level in body fluid is above normal as shown in Table I [32]. Researches on implants show that more than $90 \%$ of the failure of implants of 316L SS are due to pitting and crevice corrosion attack or fatigue failure in corrosive media [33]. Hence, it is required to improve the surface characteristics 
of $316 \mathrm{~L}$ stainless steel through bulk alloying or surface modification through corrosion resistant and biocompatible coatings even for temporary use in orthopedic device [34].

\section{SURFACE MODIFICATION AND ITS EFFECT ON CORROSION RESISTANCE AND BIOCOMPATIBILITY}

Several surface modification techniques such as chemical treatment, plasma ion implantation, plasma source ion implantation (PSII)), laser melting (LSM), laser alloying (LSA), laser nitration, ion implantation, and physical vapor deposition (PVD) have been adopted to improve corrosion resistance \& biocompatibility [35]. These methods prove to be effective over other non-conventional techniques as they provide better interfacial bonding, faster processing speed and lower pollution [36]. However, each of these modification techniques also has some limitations. Most of researchers have attempted to provide body like environment during the analysis by using simulated body fluid containing almost similar chemical composition as that of natural body fluid and maintain the normal body temperature of $37^{\circ} \mathrm{C}$ [37]. Both in-vitro and in-vivo studies are needed for the applications of biomaterial as an implant. In vitro studies, which are accomplished in simulated body condition, give an idea of the behavior of the implants under the given condition. However, it does not suggest using as implant material in the body [38]. Actual performance of biomaterial as an implant is studied through the in vivo tests. It is accomplished by inserting model of implant in an animal and analyzing its bioactivity inside body and it must be approved by FDA (Food and Drug Administration, USA) [39]. Study of In vitro corrosion behavior oforthopedic biomaterials are done in simulated body fluid mainly in Hank's solution and Ringer's solution whose components are given in Tables II and III respectively, while the corrosion performance of biomaterial used in dental application is estimated using synthetic saliva whose composition could be seen in Table IV.
The commonly used standards for corrosion testing of biomaterial are given in Table. 5[40]. Three electrode system has been used for electrochemical corrosion analysis i.e. Counter electrode, Working Electrode, and Reference Electrode. Substrate material is taken as working electrode at which oxidation/ reduction reaction occurs, the process at this are being monitored. Saturated Calomel Electrode is taken as reference electrode and platinum wire is as a counter electrode [41]. Cyclic potentiodynamic polarization and electrochemical impedance spectroscopy are the techniques employed for electrochemical analysis at $37^{\circ} \mathrm{C}$ [42].

TABLE II COMPOSITION OF HANK’s SOLUTION[43]

\begin{tabular}{|c|l|c|}
\hline S.No. & \multicolumn{1}{|c|}{ Substance } & Composition (g/l) \\
\hline 1 & $\mathrm{NaCl}$ & $8-8.5$ \\
\hline 2 & $\mathrm{KCl}$ & $0.4-0.5$ \\
\hline 3 & $\mathrm{NaHCO}_{3}$ & $0.35-0.45$ \\
\hline 4 & $\mathrm{NaH}_{2} \mathrm{PO}_{4} \cdot \mathrm{H}_{2} \mathrm{O}$ & $0.25-0.3$ \\
\hline 5 & $\mathrm{Na}_{2} \mathrm{HPO}_{4} \cdot 2 \mathrm{H}_{2} \mathrm{O}$ & 0.06 \\
\hline 6 & $\mathrm{CaCl}_{2} \cdot 2 \mathrm{H}_{2} \mathrm{O}$ & 0.19 \\
\hline 7 & $\mathrm{MgCl}_{2}$ & 0.19 \\
\hline 8 & $\mathrm{MgSO}_{4} \cdot 7 \mathrm{H}_{2} \mathrm{O}$ & $0.05-0.06$ \\
\hline 9 & $\mathrm{Glucose}$ & $1.0-3.0$ \\
\hline 10 & $\mathrm{pH}$ & $\sim 6.9$ \\
\hline
\end{tabular}

TABLE III COMPOSITION OF RiNGER’s SOLUTION[44]

\begin{tabular}{|c|l|c|}
\hline S.No. & \multicolumn{1}{|c|}{ Substance } & Composition $(\mathbf{g} / \mathbf{l})$ \\
\hline 1 & Sodium chloride & $8.5-8.7$ \\
\hline 2 & Potassium chloride & Max 0.30 \\
\hline 3 & Calcium chloride & $0.48-0.50$ \\
\hline 4 & $\mathrm{pH}$ & 6.5 \\
\hline
\end{tabular}

\begin{tabular}{|c|c|c|c|c|}
\hline \multirow{2}{*}{ S.No. } & \multicolumn{1}{|c|}{ Substance IV Composition Of ARTIFICIAL SALIVA[45] } \\
\cline { 3 - 5 } & & Xialine1 & Xialine2 & Saliveze \\
\hline 1 & Xanthan gum & 0.90 & $0.18-0.2$ & - \\
\hline 2 & Sodium carboxy methylcellulose & - & - & $10-11$ \\
\hline 3 & Potassium chloride & $1.2-1.4$ & 1.2 & 0.65 \\
\hline 4 & Sodium chloride & 0.85 & $0.85-0.9$ & 0.87 \\
\hline 5 & Magnesium chloride & 0.05 & 0.05 & 0.06 \\
\hline 6 & Calcium chloride & 0.13 & 0.13 & 0.17 \\
\hline 7 & Di-potassium hydrogen orthophosphate & 0.14 & 0.14 & 0.85 \\
\hline 8 & Potassium di-hydrogen orthophosphate & - & - & 0.30 \\
\hline 9 & Sodium fluoride & - & - & 0.0044 \\
\hline 10 & Sorbitol & - & - & 29.95 \\
\hline 11 & Methyl p-hydroxybenzoate & 0.35 & 0.35 & 1 \\
\hline 12 & pH & Neutral & Neutral & Neutral \\
\hline
\end{tabular}


TABLE V STANDARD OF CORROSION TeSt[40]

\begin{tabular}{|c|l|l|}
\hline S.No. & ASTM standard & \multicolumn{1}{c|}{ Specifications } \\
\hline 1 & $\begin{array}{l}\text { ASTM G 61-86, } \\
\text { and ASTM G 5-94 }\end{array}$ & Corrosion performance ofmetallic biomaterials \\
\hline 2 & ASTM G71-81 & Galvanic corrosion in electrolytes \\
\hline 3 & ASTM F746-87 & Pitting or crevice corrosion of metallic implants \\
\hline 4 & ASTM F2129-01 & Cyclic potentiodynamic polarization \\
\hline
\end{tabular}

Antuneset al. [46] studied the corrosion behavior in hank's solution and biocompability of TiCN coated $316 \mathrm{~L}$ stainless steel. It has been found that TiCN-coated steel is more prone to corrosion as compared to bare sample due to the presence of surface defect on material. According to authors, the electrolyte penetrates through the defect and leads to reduction in impedance value as seen by electrochemical impedance spectroscopy. They perform cytotoxicity and genotoxicity test to check biocompability. They suggested suitability of TiCN coated SS for biomedical devices, however, there is scope for improvement in corrosion resistance for its application as real implants device.

Similar study has been done by Subramanian [47] for coating of $\mathrm{TiN} / \mathrm{NbN}$ on $316 \mathrm{~L}$ SS through DC magnetron sputtering. They carried out corrosion analysis in SBF fluid by potentiodynamic polarization and studied biocompatibity in term of bacterial adhesion to the surface. They observed more positive $\mathrm{E}_{\text {corr }}$ and lower $\mathrm{I}_{\text {corr }}$ value obtained from tafel plot for TiN/NbN multilayer coating as compare to bare 316 $\mathrm{L}$ suggesting better corrosion resistance probably due to more uniform surface of TiN/NbN surface. They obtainedEpi-fluorescence microscopy image which shows less bacteria cover for TiN/NbN coated substrate and more bacterial adhesion in bare 316 L SS signifies better biocompatibility for coated substrate in the presence of oral bacteria.

Chenglonget al. [48] have studied the corrosion behavior in TSBF and hemocompatibilty through platelet adhesion test ofTiN and Ti/TiN coated $316 \mathrm{~L} \mathrm{SS}$. Result shows more positive value of $E_{\text {corr }}$ and less $I_{\text {corr }}$ value for Ti/TiN multilayer SS as compare to single layer $\mathrm{TiN}$ and bare substrate suggesting better corrosion resistance for bilayer coating. The author's also analysedhemocompatibilty through adhesion of globulin and fibrinogen on implants and obtained higher clotting time on coated sample than bare $316 \mathrm{~L}$ i.e. better hemocompatibilty.

Conradiet al. [49] analyzed the corrosion behavior of $316 \mathrm{~L}$ SS and 2205 duplex SS in artificial saliva and hank solution. They have seen that 2205 duplex SS is stable in both the medium i.e in artificial saliva and hank's solution, however, $316 \mathrm{~L} \mathrm{SS}$ is stable in artificial saliva but prone to pitting in hank's solution due to high chloride content in the solution. Das \&Shukla [50] studied the bioactivity (in SBF) and antibacterial efficacy of Hydroxyapatite (HAp) coated 254 stainless steel deposited by RF magnetron sputtering method.They investigated In vitro antibacterial efficacy of the bare and HA-coated samples against Escherichiacoli (E. coli) using the Fluorescence Activated Cell Sorting (FACS) technique and found less bacterial growth as compared to bare sample as FSC and SSC values are less for the coated substrate. The apatite layer formed on the HAp coated substrate is shown in Fig.1.
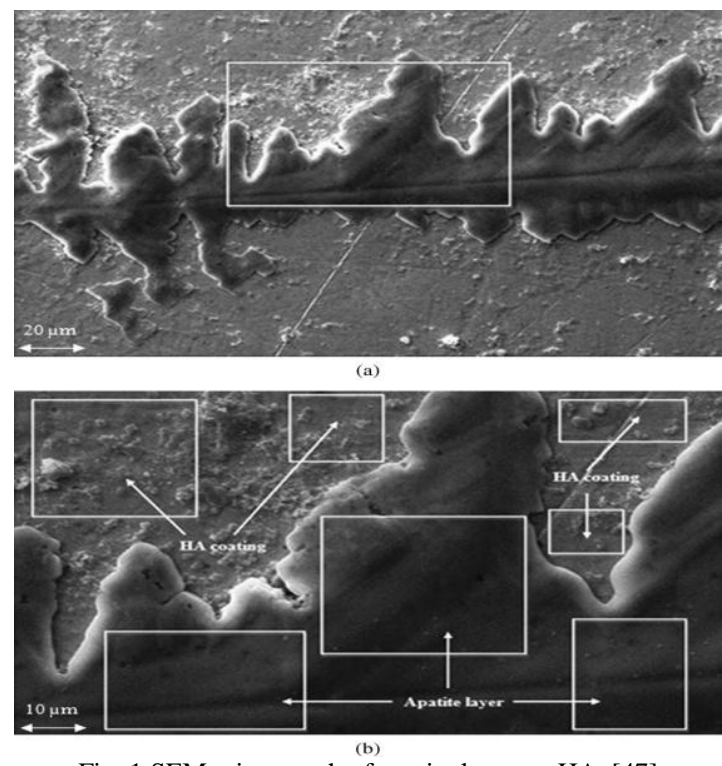

Fig. 1 SEM micrograph of apatite layer on HAp[47]

Similar work has been done by Das \&Shukla [51] by using laser` rapid manufacturing and results are very close to coating done by RF magnetron sputtering.

Dinuet al. [52]investigated the corrosion properties of $\mathrm{CrN}$, $\mathrm{Cr}(\mathrm{N}, \mathrm{O})$ coating on $304 \mathrm{SS}$ throughreactive cathode arc method in $0.10 \mathrm{M} \mathrm{NaCl}+1.96 \mathrm{M} \mathrm{H}_{2} \mathrm{O}_{2}$ at $24^{\circ} \mathrm{C}$. They observed more positive $\mathrm{E}_{\text {corr }}$ value and less $\mathrm{I}_{\text {corr }}$ value for $\mathrm{CrN} / \mathrm{Cr}(\mathrm{N}, \mathrm{O})$ followed by $\mathrm{Cr}(\mathrm{N}, \mathrm{O}) / \mathrm{CrN}$ obtained from potentiodynamicpolarization test. They reported better corrosion resistance of bilayer coating as compare to single layer and bare substrate. They concluded that it is due to fact that bilayer coating is less porous, denser and has strong adherence to substrate. Similar work has been done by Huang et al. [53] on SS304 and studied the corrosion in $\mathrm{CaCl}_{2}$ and evaluated the biomechanicalproperties of CrAlTiN, CrN/NbN coated stainless steel deposited through magnetron sputtering. The corrosion Tafel test results showed that the metal-nitride coatings provides better corrosion resistance. Among them, $\mathrm{CrN} / \mathrm{NbN}$-coated substrates showed better corrosion resistance compared to the CrAlTiN-coating. In evaluating the biocompatibility of the CrAlTiN and $\mathrm{CrN} / \mathrm{NbN}$ coatings, the human cell line 
MDA-MB-231 was found to attach and proliferate well on the surfaces of the two coatings.

Kuroda et al.[54] investigated the corrosion resistance of Nickel free high nitrogen content (HNSS) and compared it with most widely used $316 \mathrm{~L}$ stainless steel in $0.9 \% \mathrm{NaCl}$ solution (saline), phosphate buffered saline PBS, Hanks' solution (Hanks) and Eagle's minimum essential medium (E-MEM). The HNSS shows better pitting corrosion resistance in all electrolytes for the tested polarization range than $316 \mathrm{~L}$. $\mathrm{I}_{\text {corr }}$ in Hanks of HNSS was lower than that in saline, which indicates improvement in pitting resistance due to existence of inorganic ions such as phosphate and calcium ions. However, $\mathrm{I}_{\text {corr }}$ in E-MEM was higher than that in Hanks, but was lower than that in saline. Further, due to less content of $\mathrm{Ni}$, it is more biocompatible compare to 316 L.

Oje\&Ogwu [55] analyzed the chromium oxide coating deposited on $316 \mathrm{~L} \mathrm{SS}$ by RF magnetron sputtering method at oxygen flow rate of 4, 8, 10 standard cubic centimeter $(\mathrm{sccm})$. Electrochemical corrosion test has been performed in ringer's physiological solution at $37^{\circ} \mathrm{C}$. Corrosion current density is found lower for coated substrate as compare to uncoated for all values of oxygen flow rate. However, coated substrate at $\mathrm{O}_{2}$ flow rate of 4 sccmshowed more positive $\mathrm{E}_{\text {corr }}$ and less $\mathrm{I}_{\text {corr }}$ value from potentiodynamicpolarization test and high impedance value from EIS measurement indicating best improvement in corrosion resistance. Biocompatibility of coating is studied in terms of chromium release which is very low as compared to specific level in fluid.

Paraspuret al. [56] studied the corrosion resistance (in ringer's solution) and biocompatibility of stainless steel through surface treatment by $\mathrm{H}_{2} \mathrm{SO}_{4}$ and $\mathrm{HNO}_{3}$ and compared it with $\mathrm{Nb}$ coating. They found that the corrosion resistance and biocompatibility of $\mathrm{Nb}$ coated stainless steelis better than surface treated whereas $\mathrm{H}_{2} \mathrm{SO}_{4}$ surface treated showed better performance in ringer's solution as compared to $\mathrm{HNO}_{3}$ asitsI $\mathrm{I}_{\text {corr }}$ value is higher.

Subhramanian\&Jaychandran[57] have investigated the electrochemical corrosion (in SBF fluid at $37^{\circ} \mathrm{C}$ ) resistance and hemocompatibility (Platelet adhesion) of TiN and TiN/Ni coated $316 \mathrm{~L} \mathrm{SS}$. In bilayer coating, Ni was deposited through brush plating. They obtained optimum $\mathrm{E}_{\text {corr }}$ and $\mathrm{I}_{\text {corr }}$ valuesfrom potentiodynamic polarization test for TiN/Ni bilayer coated substrate followed by TiN coated and bare $316 \mathrm{~L}$ stainless steel. They examined Platelet adhesion is between blood and substrates and found maximum for TiN/Ni bilayer as compare to bare substrate suggesting better hemocompatibility.

Zhao et al. [58] analyzed the corrosion behavior of coatings deposited by different thermal spray technique i.e. HVOF, SPS, \&APS. Corrosion resistance through HVOF coating isfoundsuperior to SPS, and APS as coating was denser and oxides content were less.
Composite coating of amorphous carbon and titanium on 316 L SS has been done through magnetron sputtering by Dhandapaniet al. [59]. They have investigated tribological properties, corrosion resistance (in $\mathrm{SBF}$ at $37^{\circ} \mathrm{C}$ ) and biocompatibility (in terms of cell adhesion) of coating with varying wt. $\%$ of Titanium. It has found that at higher weight percentage of titanium demonstrate, good cell adhesion, excellent resistance to corrosion and substantially better tribological properties than the other coatings compositions. It has seen that due formation of $\mathrm{TiC}$ after the reinforcing the $\mathrm{Ti}$ into $\mathrm{C}$-matrix results improvement in corrosion resistance and also increases the hydrophobic nature of coating and enhance the cell adhesion. Improvement in wear rate and decrease in friction is attributed to better mechanical properties and formation of $\mathrm{sp}^{2}$ clusters due to increased Ti content.

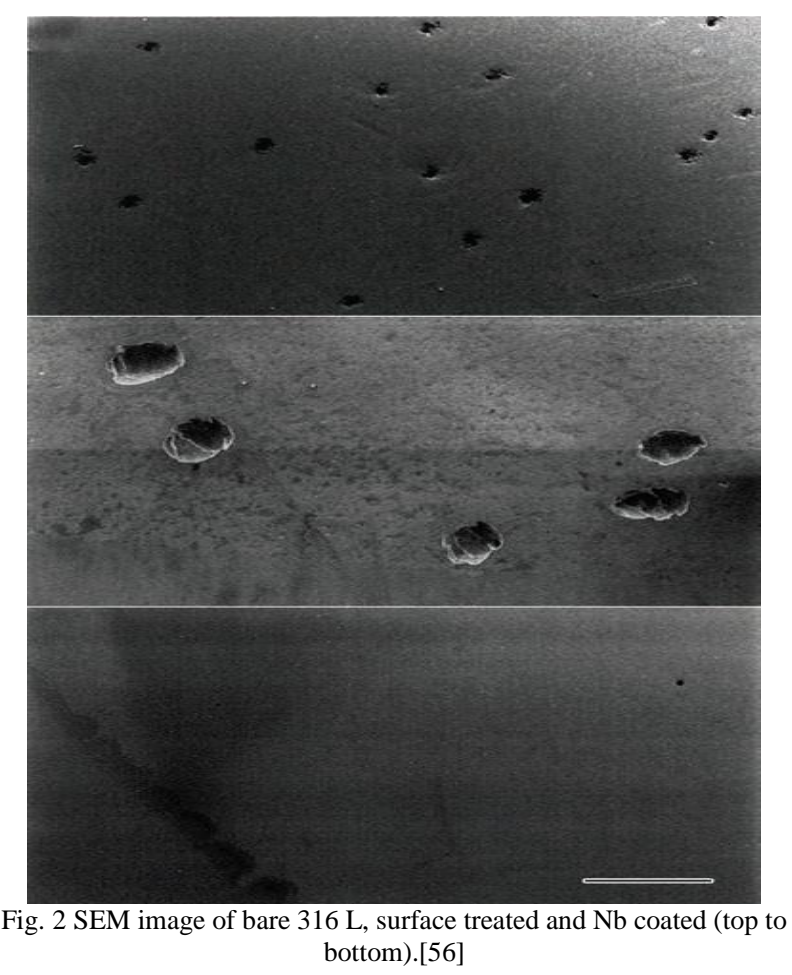

\section{CONCLUSION}

The stainless steel material for dental, orthopedic and cardiovascular implants are still suffering from corrosion and wear problem and need more attention.Stainless steels especially $316 \mathrm{~L}$ and, 304grades largely are used due to ease of availability, cheapness, and satisfactory mechanical and tribological properties (as implants material particularly in case of orthopedic, hip replacement and dental applications). However, stainless steels undergo severe wear and corrosion, and, release elements such as $\mathrm{Ni}, \mathrm{Mo}, \mathrm{Al}, \mathrm{Co}$ etc. which can cause detrimental effects on the human body and restrict its use for long period of time. These can be controlled through surface modification by coating and nitrogen implantation. Bio-ceramics such as hydroxyapatite 
coatings are widely used on the implants due to their high compatibility with human tissues and bonesbutcorrosion resistance is not up to the mark and as more prone to load applications. In order to counter above problem, ceramic coatings based on titanium, chromium, niobium, aluminum etc. have been attempted by various investigators and showed better behavior as compare to bio ceramic coatings under various load. However, composite coating of hydroxyapatiteand ceramic (Metallic oxides and nitrides) such as $\mathrm{HA} / \mathrm{TiN}, \mathrm{HA} / \mathrm{TiO}_{2}$ etc. have been shown ability to improve the biocompatibility and large load bearing capacity which makes its suitability for applications such as joint replacements. Most of researchers has modified surface through plasma nitridingandimprove properties significantly but improvement is not found comparable to the coatings.

\section{REFERENCES}

[1] M. Geetha, A.K. Singh,R Asokamani, AK.Gogia, "Ti based biomaterials, the ultimate choice for orthopaedic implants-A review," Progress In Materials Science, Vol. 54, No. 3, pp. 397-425, 2009.

[2] S. Ramakrishna, J. Mayer,E. Wintermantel, Leong, K.W., "Biomedical applications of polymer-composite materials: A review," Composites Science and Technology, Vol. 61, No. 9, pp. 1189-1224, 2001.

[3] M. Long, H.J. Rack, "Titanium alloys in total joint replacement-A materials science perspective," Biomaterials, Vol. 19, No. 18, pp. 1621-1639, 1998.

[4] M. Talha,C.K. Behera,O.P. Sinha, "A review on nickel-free nitrogen containing austenitic stainless steels for biomedical applications. Materials Science and Engineering: C," Vol. 33, No. 7, pp. 35633575, 2013.

[5] A. Shahryari,S. Omanovic,J.A. Szpunar, "Electrochemical formation of highly pitting resistant passive films on a biomedical grade 316LVM stainless steel surface," Materials Science and Engineering: C, Vol. 28, No. 1, pp. 94-106, 2008.

[6] D.F. Williams,"Current perspectives on implantable devices," India: Jai Press, Vol. 2, pp. 47-70, 1990.

[7] Q. Chen, G.A. Thouas, "Research Reports- Metallic implant biomaterials," Materials Science and Engineering,Vol. 87, pp. 1-57, 2015.

[8] C. Ergun,R.H. Doremus,W.A. Lanford, "Interface reaction/diffusion in hydroxylapatite-coated SS316L and CoCrMo alloys," Acta Materialia, Vol. 52, No. 16, pp. 4767-4772, 2004.

[9] C. Dee, Kay,A. David, Puleo, and Rena Bizios, An introduction to tissue-biomaterial interactions, John Wiley \& Sons, pp. 53-88, 2003.

[10] K. Nielsen, "Corrosion of metallic implants," British Corrosion Journal, Vol. 22, No. 4, pp. 272-278, 1987.

[11] S. I. Virtanen, E. Milošev, R. Gomez-Barrena, J. Trebše, Salo,Y.T. Konttinen, "Special modes of corrosion under physiological and simulated physiological conditions," Acta Biomaterialia, Vol. 4, No. 3, pp. 468-476, 2008.

[12] A. Kocijan,I. Milošev,B. Pihlar, "The influence of complexing agent and proteins on the corrosion of stainless steels and their metal components," Journal of Materials Science: Materials in Medicine, Vol. 14, No. 1, pp. 69-77, 2003.

[13] Z.H. Zhen,T.F. Xi,Y.F. Zheng, "A review on in vitro corrosion performance test of biodegradable metallic materials," Transactions of Nonferrous Metals Society of China, Vol. 23, No. 8, pp. 22832293, 2013.

[14] X.U.Congmin,Y. ZHANG,G. CHENG, and Z.H.U. Wensheng, "Corrosion and Electrochemical Behavior of 316L Stainless Steel in Sulfate-reducing and Iron-oxidizing Bacteria Solutions," Chinese Journal of Chemical Engineering, Vol. 14, No. 6, p.829-834,2006.

[15] RT.Loto, "Pitting corrosion evaluation and inhibition of stainless steels: A review," Journal of Material Environmental Science, Vol. 6, No. 10, pp. 2750-2762, 2015.
[16] G.T. Burstein, C.Liu, R.M. Souto S.P.Vines, "Origins of pitting corrosion," Corrosion Engineering, Science and Technology, Vol. 39, No. 1, pp. 25-30, 2004.

[17] J.W.Schultze, Lohrengel, M.M., "Stability, reactivity and breakdown of passive films," Problems of recent and future research. Electrochimica Acta, Vol. 45, No. 15-16, pp. 2499-2513, 2000.

[18] M.Sivakumar,U.K.Mudali, Rajeswari, "Compatibility of ferritic and duplex stainless steels S.as implant materials: in vitro corrosion performance," Journal of Materials Science, Vol. 28, No. 22, pp. 6081-6086, 1993.

[19] Y.Wang,G.Cheng,W.Wu,Q.Qiao,Y.Li,X.Li, "Effect of pH and chloride on the micro-mechanism of pitting corrosion for high strength pipeline steel in aerated $\mathrm{NaCl}$ solutions," Applied Surface Science, Vol. 349, pp. 746-756, 2015.

[20] I.Milošev,H.H.Strehblow, "The composition of the surface passive film formed on CoCrMo alloy in simulated physiological solution," Electrochimica Acta, Vol. 48, No. 19, pp. 2767-2674, 2003.

[21] J.W.Oldfield, and W.H.Sutton, "Crevice corrosion of stainless steels: II. Experimental studies," British Corrosion Journal, Vol. 13, No. 3, pp. 104-111, 1978 .

[22] R.A.Antunes, and M.C.L. De Oliveira, "Corrosion fatigue of biomedical metallic alloys: mechanisms and mitigation," Acta biomaterialia, Vol. 8, No. 3, pp. 937-962, 2012.

[23] J.F.Bates, "Cathodic protection to prevent crevice corrosion of stainless steels in halide media," Corrosion, Vol. 29, No. 1, pp. 2832, 1973.

[24] N.Azzerri,F.Mancia, and A.Tamba, "Electrochemical prediction of corrosion behaviour of stainless steels in chloride-containing water," Corrosion Science, Vol. 22, No. 7, pp. 675-687,1982.

[25] J.Soltis, "Passivity breakdown, pit initiation and propagation of pits in metallic materials-review," Corrosion Science, Vol. 90, pp. 522,2015.

[26] D.Singh,R.Singh andK. S.Boparai, "Development and surface improvement of FDM pattern based investment casting of biomedical implants: A state of art review," Journal of Manufacturing Processes, Vol. 31, pp. 80-95, 2018.

[27] Hanawa, Takao, "Reconstruction and regeneration of surface oxide film on metallic materials in biological environments,"Corrosion Reviews, Vol. 21, pp. 161-182,2003.

[28] Manivasagam, U.Geetha,R.Kamachi Mudali, Asokamani. and Baldev Raj,"Corrosion and microstructural aspects of titanium and its alloys as orthopaedic devices," Corrosion Reviews, Vol. 21, pp. 125-160, 2003.

[29] M.Mohanty,S.Baby and K. V.Menon, "Spinal fixation device: A 6year postimplantation study," Journal of biomaterials applications, Vol. 18, No. 2, pp. 109-121, 2003.

[30] Jacobs, J.Joshua, L.Jeremy, Gilbert, and Robert M, Urban,"Corrosion of metal orthopaedic implants," The Journal of Bone and Joint Surgery, Vol.80, No. 2, pp. 268-282, 1998.

[31] Chu, K.Paul, J. Y.Chen, L. P.Wang, and Nan Huang., "Reasearch Reports-Plasma-surface modification of biomaterials," Materials Science and Engineering, Vol. 36, No. 5-6, pp. 143-206, 2002.

[32] G.Manivasagam, D.Dhinasekaran, and A.Rajamanickam, "Biomedical implants: corrosion and its prevention-A review,"Recent patents on corrosion science, Vol. 2, pp. 40-54, 2010.

[33] M.Z.Ibrahim,A.A.Sarhan, F.Yusuf, and M.Hamdi, "Biomedical materials and techniques to improve the tribological, mechanical and biomedical properties of orthopedic implants-a review article," Journal of Alloys and Compounds, Vol. 714, pp. 636-667, 2017.

[34] S.Al Saadi,Y.Yi,P.Cho,C. Jang and P.Beeley, "Passivity breakdown of 316L stainless steel during potentiodynamic polarization in $\mathrm{NaCl}$ solution," Corrosion Science, Vol. 111, pp. 720-727,2016.

[35] Singh, Raghuvir and B. Narendra, Dahotre., "Corrosion degradation and prevention by surface modification of biometallic materials," Journal of Materials Science: Materials in Medicine, Vol. 18, No. 5, pp. 725-751, 2007.

[36] Anil Kurella and B. Narendra, Dahotre,"Surface modification for bioimplants: the role of laser surface engineering," Journal of biomaterials applications, Vol. 20, No. 1, pp. 5-50, 2005.

[37] Kumar, Satendra. TSN Sankara Narayanan, S. Ganesh Sundara Raman. and S. K. Seshadri, "Thermal oxidation of CP-Ti: Evaluation of characteristics and corrosion resistance as a function of treatment time," Materials Science and Engineering: C, Vol. 29, No. 6, pp. 1942-1949, 2009. 
[38] L.Klein, Christoph, Holger, Köhler. and James Kirkpatrick. "Increased adhesion and activation of polymorphonuclear neutrophil granulocytes to endothelial cells under heavy metal exposure in vitro," Pathobiology, Vol. 62, No. 2, pp. 90-98, 1994.

[39] Gal, Jean-Yves. Yannick, Fovet. and Myriam, Adib-Yadzi., "About a synthetic saliva for in vitro studies," Talanta, Vol. 53, No. 6, pp. 1103-1115, 2001.

[40] J.Yu,Z. J.Zhao, and L. X.Li, "Corrosion fatigue resistances of surgical implant stainless steels and titanium alloy," Corrosion Science, Vol. 35, No. 1-4, pp. 587-597, 1993.

[41] P.J.Aragon, and S.F.Hulbert, "Corrosion of Ti-6Al-4V in simulated body fluids and bovine plasma," Journal of Biomedical Materials Research, Vol. 6, No. 3, pp. 155-164,1972.

[42] K. R.Jagdeo,S.Kadam andM. R.Nair, "Electrochemical corrosion behaviour of nitrogen ion implanted 316L stainless steel in Ringer Lactate solution," Int. Refereed J. Eng. Sci., Vol. 1, No. 4, pp. 0106, 2012.

[43] JE Gonzalez, JC. Mirza-Rosca, "Study of the corrosion behavior of titanium and some of its alloys for biomedical and dental implant applications," Journal of Electroanalytical Chemistry, Vol. 471, No. 2, pp. 109-115, 1999.

[44] KJ. Bundy, "Corrosion and other electrochemical aspects of biomaterials," Critical Reviews In Biomedical Engineering, Vol. 22, No. 3-4, pp. 139-251, 1994.

[45] A Preetha, R. Banerjee, "Comparison of artificial saliva substitutes," Trends Biomater Artif Organs, Vol. 18, No. 2, pp. 178-186, 2005.

[46] R.A. Antunes, A.C.D. Rodas, N.B. Lima, O.Z. Higa, and I. Costa, "Study of the corrosion resistance and in vitro biocompatibility of PVD TiCN-coated AISI $316 \mathrm{~L}$ austenitic stainless steel for orthopedic applications," Surface and Coatings Technology, Vol. 205, No. 7, pp. 2074-2081, 2010.

[47] Subramanian, B. "Enhancement of biocompatibility of metal implants by nanoscale TiN/NbN multilayer coatings," Journal of Nanoscience and Nanotechnology, Vol. 13, No. 7, pp. 4565-4572, 2013.

[48] L. Chenglong, Y. Dazhi, L. Guoqiang, and Q. Min, "Corrosion resistance and hemocompatibility of multilayered Ti/TiN-coated surgical AISI 316L stainless steel," Materials letters, Vol. 59, No. 2930, pp. 3813-381,20059.

[49] M. Conradi, P.M. Schön, A. Kocijan, M. Jenko, and G.J. Vancso, "Surface analysis of localized corrosion of austenitic 316L and duplex 2205 stainless steels in simulated body solutions," Materials Chemistry and Physics, Vol. 130, No. 1-2, pp. 708-713,2011.
[50] A. Das, and M. Shukla, "Surface morphology and in vitro bioactivity of biocompatible hydroxyapatite coatings on medical grade S31254 steel by RF magnetron sputtering deposition," Transactions of the $I M F$, Vol. 95 , No. 5, pp. 276-281,2017.

[51] A. Das, and M. Shukla, "Hydroxyapatite coatings on high nitrogen stainless steel by laser rapid manufacturing," JOM, Vol. 69, No. 11, pp. 2292-2296, 2017.

[52] M. Dinu, E.S.M. Mouele, A.C. Parau, Vladescu, A. Petrik, L.F. and Braic, M. "Enhancement of the Corrosion Resistance of 304 Stainless Steel by $\mathrm{Cr}-\mathrm{N}$ and $\mathrm{Cr}(\mathrm{N}, \mathrm{O})$ Coatings," Coatings, Vol. 8, No. 4, pp. $132,2018$.

[53] W. Huang, E. Zalnezhad, F. Musharavati, and P. Jahanshahi, "Investigation of the tribological and biomechanical properties of CrAlTiN and CrN/NbN coatings on SST 304," Ceramics International, Vol. 43, No. 11, pp. 7992-8003, 2017.

[54] D. Kuroda, S. Hiromoto, T. Hanawa, and Y. Katada, "Corrosion behavior of nickel-free high nitrogen austenitic stainless steel in simulated biological environments," Materials Transactions, Vol. 43, No. 12, pp. 3100-3104,2002.

[55] A.M. Oje, and A.A. Ogwu, "Chromium oxide coatings with the potential for eliminating the risk of chromium ion release in orthopaedic implants," Royal Society Open Science, Vol. 4, No. 7, pp. $1702-1718,2017$

[56] A. Parsapour, S.N. Khorasani, and M.H. Fathi, "Effect of surface treatment and metallic coating on corrosion behavior and biocompatibility of surgical 316L stainless steel implant," Journal of Materials Science \& Technology, Vol. 28, No. 2, pp. 125-131, 2012.

[57] B. Subramanian, and Jayachandran, "Electrochemical corrosion behavior of magnetron M. sputtered TiN coated steel in simulated bodily fluid and its hemocompatibility," Materials Letters, Vol. 62, No. 10-11, pp. 1727-1730,2008

[58] L. Zhao, and E. Lugscheider, "Influence of the spraying processes on the properties of 316L stainless steel coatings," Surface and Coatings Technology, Vol. 162, No. 1, pp .6-10.,2003

[59] V.S. Dhandapani, R. Subbiah, E. Thangavel, M. Arumugam, K. Park, Z.M. Gasem, V. Veeraragavan, and D.E. Kim, "Tribological properties, corrosion resistance and biocompatibility of magnetron sputtered titanium-amorphous carbon coatings," Applied Surface Science, Vol. 37, No. 1, pp. 262-274,2016. 